\title{
Análise do processo de recuperação de serviços a partir das reclamações dos clientes: estudo de caso em três organizações
}

\author{
Daniel Battaglia ${ }^{\mathrm{a}, *}$, Miriam Borchardt ${ }^{\mathrm{b}}$ \\ a,**danielb@portoweb.com.br, UNISINOS, Brasil \\ bmiriamb@unisinos.br, UNISINOS, Brasil
}

\section{Resumo}

0 objetivo deste trabalho é apresentar uma análise do processo de recuperação de serviços realizado a partir das reclamações dos clientes e de como as melhorias dos processos são efetuadas nas empresas. 0 trabalho apresenta conceitos relativos a expectativas e percepções, falhas e reclamações, recuperação de serviços e melhoria da qualidade em serviços. 0 método de pesquisa utilizado é o estudo de caso, que foi empregado em três organizações: uma empresa com alto grau de contato com cliente e serviço personalizado; uma empresa atuante no varejo com médio grau de contato, e uma empresa com baixo grau de contato com o cliente por se tratar de um serviço de massa. Ao final, discutem-se os resultados e encaminha-se a continuidade da pesquisa. Os achados da pesquisa sugerem a necessidade de uma estratégia de recuperação de serviços atrelada à melhoria dos processos, de modo a fornecer o serviço certo já na primeira vez.

Palavras-chave

Recuperação de serviços. Reclamações em serviços. Melhoria da qualidade em serviços.

\section{Introdução}

A prestação de serviços é o centro das atividades econômicas do mundo moderno, sendo essencial para o desenvolvimento das sociedades atuais (LOVELOCK; WRIGHT, 2004). A intangibilidade dos serviços, caracterizados por ideias e conceitos, difere da relação que se estabelece com os produtos, que são objetos; esse fato pode significar uma nova alternativa para a introdução de inovações constantes nas organizações.

A satisfação dos clientes é crucial para a sobrevivência de qualquer organização. No entanto, as operações de serviços são usualmente complexas, baseadas nas relações humanas entre o consumidor e o funcionário da linha de frente (JOHNSTON, 2001; BOSCH; ENRIQUEZ, 2006). Consequentemente, em serviços, erros, enganos e falhas são inevitáveis, requerendo das organizações ações relativas à recuperação do serviço (JOHNSTON; MICHEL, 2008). Os Autores sugerem inclusive que um bom gerenciamento de reclamações e a recuperação de serviços imediatamente após a falha deveriam constituir prática geral nas estratégias das organizações com relação à satisfação dos clientes.
0 tema 'gerenciamento das reclamações e recuperação de serviços' comparece na literatura pesquisada. Citam-se, como exemplos: Stauss (2002), que investiga os principais construtos envolvidos na satisfação dos clientes após uma reclamação; Kau e Loh (2006), que comparam a satisfação de consumidores reclamantes e não reclamantes; Johnston (2001) sugere que as reclamações deveriam servir de oportunidade para que as organizações melhorem seus processos e o desempenho financeiro; Mattila (2001), que discute a efetividade da recuperação do serviço; Lidén e Skalén (2003), que relacionam o efeito da garantia em serviços com a recuperação do serviço, e Michel (2001), que analisa as falhas em serviços e os respectivos processos de recuperação.

Não obstante tais abordagens, Johnston e Michel (2008) observam que poucas organizações adotam políticas eficazes que permitam ouvir as reclamações dos seus clientes e identificar possíveis insatisfações. Para Fitzsimmons, J.; Fitzsimmons, M. (2005), cerca de $4 \%$ dos clientes insatisfeitos com o serviço são ouvidos pelas empresas e, dos 96\% restantes, 25\% 
têm problemas graves ou sérios. Estas informações sugerem que um dos problemas enfrentados pelas organizações relaciona-se com a captação de informações, a fim de recuperar eficientemente um determinado serviço. Por outro lado, a intenção de os reclamantes, plenamente satisfeitos com o retorno de uma reclamação, voltarem a utilizar um determinado serviço chega a 80\% (LOVELOCK; WRIGHT; 2004).

Ressalta-se, ainda, que os clientes são cada vez mais exigentes, sendo essencial um maior comprometimento das organizações a fim de satisfazerem suas necessidades. Tal aspecto tem levado as organizações a buscarem alternativas para atingirem a excelência no bom atendimento (BATESON e HOFFMAN, 2001; LOVELOCK; WRIGHT, 2004; FITZSIMMONS J.; FITZSIMMONS M., 2005). Em termos de pesquisas acadêmicas, Johnston (2005) mostra o crescimento das publicações relativas a operações de serviços a partir da década de 1980 bem como a evolução das abordagens utilizadas.

Este trabalho tem como objetivo geral analisar o processo de recuperação do serviço, desencadeado a partir das reclamações dos clientes, além de verificar como as melhorias dos processos são efetuadas nas empresas, através da investigação em três estudos de casos. Os estudos foram efetuados em: (i) uma empresa classificada como serviço de massa, em que há um baixo grau de contato entre prestador de serviço e o cliente; a ênfase da gestão centra-se nos equipamentos e na administração de hierarquias rígidas, com necessidade de padronizar processos; há elevado investimento em marketing e praticamente não há customização; (ii) uma loja de serviço, em que é médio o grau de contato entre o prestador de serviço e o cliente, podendo haver certo grau de customização; as decisões gerenciais relacionam-se com as decisões de capital e os avanços tecnológicos, assim como com o gerenciamento da demanda, e (iii) uma empresa de serviços profissionais, em que o grau de contato é alto; há personalização do serviço e o enfoque gerencial centra-se nas pessoas, na capacitação contínua da equipe de trabalho e na programação da força de trabalho. A classificação relativa ao grau de contato entre o prestador de serviço e o cliente segue a proposta por Lovelock e Wright (2004).

Dessa maneira, pretende-se fazer uma análise acerca do processo de recuperação das empresas investigadas, a fim de compreender melhor as variáveis envolvidas em cada caso. 0 método de pesquisa utilizado não permite generalizações.

0 artigo apresenta inicialmente uma revisão teórica, por meio da qual se buscam subsídios e embasamentos necessários para ampliar a compreensão acerca do assunto. A seguir, são descritos os casos que fazem parte do estudo. Por fim, é feita a complementação, através das considerações finais, para se exporem as conclusões obtidas neste trabalho.

\section{Referencial teórico}

\subsection{Classificação dos serviços quanto ao grau de contato do cliente}

0 encontro de serviço se caracteriza por ser um período de tempo durante o qual os clientes interagem diretamente com um serviço (BATESON; HOFFMAN, 2001). Em alguns casos, a experiência de serviço pode ser reduzida a um único encontro, com o pedido, o pagamento e a execução da entrega ocorrendo no mesmo lugar. Em outros casos, a experiência do cliente abrange uma sucessão de encontros que pode se distribuir por um determinado período de tempo, envolver vários funcionários e até acontecer em lugares diferentes. À medida que aumenta o nível de contato do cliente com a operação de serviço, tende a haver encontros de serviços mais numerosos e demorados.

Nesse sentido, Lovelock e Wright (2004) propõem três níveis de contato do cliente, representando o grau de interação com o pessoal de serviços, com os elementos físicos do serviço ou com ambos. Os serviços de alto contato tendem a ser aqueles nos quais os clientes, ao longo da prestação do serviço, são ativamente envolvidos. Lovelock e Wright (2004) citam como exemplos: corte de cabelo, consultoria em administração e enfermagem em casa.

Os serviços de médio contato exigem menos envolvimento com os fornecedores de serviços. Esses serviços envolvem situações em que os clientes visitam as instalações do fornecedor do serviço e mantêm um contato moderado com o pessoal de serviços. Os Autores citam como exemplos: reparo de automóveis, lavanderia, banco operado por telefone e loja de varejo.

Os serviços de baixo contato envolvem pouco ou nenhum contato direto entre clientes e fornecedores de serviço. 0 contato ocorre em uma base impessoal, por meio de canais de distribuição eletrônicos ou físicos. Citam-se como exemplos: serviços pela Internet, home banking, TV a cabo e fornecimento de energia elétrica.

0 grau de contato influencia diversos aspectos das operações de serviços. Para Fitzsimmons e Fitzsimmons (2005), serviços com baixo contato 
tendem a priorizar o uso da estrutura e dos recursos físicos, estimulando a padronização das ações. No outro extremo da classificação em relação ao nível de contato, serviços com alto grau de contato nem sempre focam a maximização do uso da estrutura; muitas vezes, baseiam-se nas relações pessoais entre o cliente e o pessoal de contato para alavancar novos negócios.

No contexto descrito, interessa neste trabalho avaliar o processo de recuperação de serviços e o modo como as melhorias são incorporadas aos processos para cada grau de contato - baixo, médio e alto - do cliente com o prestador do serviço.

\subsection{Expectativas e percepções em serviços}

Para Bateson e Hoffman (2001), o que importa é o serviço percebido, não o serviço verdadeiro. Tal afirmação remete para a análise acerca das expectativas e das percepções. Segundo Coye (2004), é comum as expectativas relacionarem-se com aquilo que os clientes consideram como sendo o serviço ideal ou excelente.

Ampliando a discussão acerca das possíveis formas de expectativas, Zeithaml e Bitner (2003) classificam as mesmas como: (i) expectativas como prognósticos; (ii) expectativas como ideais; (iii) expectativas baseadas em experiência; (iv) expectativas com tolerâncias mínimas; (v) expectativas de merecimento, e (vi) expectativas comparativas. As Autoras salientam, ainda, que o processo de expectativa é complexo, sendo completamente possível - e até provável - que mais de uma forma de expectativa funcionarão simultaneamente.

Baseados nos tipos variáveis de expectativas, os consumidores avaliam o desempenho dos serviços usando dois padrões. Em primeiro lugar, existe o nível de serviço desejado por eles, o que poderia ser chamado de serviço máximo aceitável; em segundo, há um nível de serviço que consideram adequado, que poderia ser chamado de mínimo aceitável. Entre esses dois, há a zona de tolerância, aceitável pelos consumidores em determinadas circunstâncias (ZEITHAML; BITNER, 2003; FITZSIMMONS J.; FITZSIMMONS M., 2005; COYE, 2004). No contexto exposto, Berry (2001) considera que a zona de tolerância é a zona que requer maior atenção, pois é nela que se encontra a possibilidade de tornar o cliente satisfeito, por meio de um bom serviço, ou então tornar o serviço inaceitável pela má prestação do mesmo ao consumidor final.

A avaliação do desempenho dos serviços denomina-se percepção e refere-se ao modo como o cliente enxerga o serviço prestado, avaliando se este foi adequado ou não (GLYNN et al., 2003). 0 modo como os clientes avaliam os serviços ao longo do tempo tem um comportamento dinâmico, podendo sofrer alterações ao longo desse interim e de pessoa para pessoa. Os clientes percebem os serviços em termos de qualidade dos serviços e avaliam o quanto estão satisfeitos com respeito ao conjunto total de suas experiências de serviços. A mensuração da satisfação dos clientes resulta da comparação entre o serviço previsto e o percebido; por outro lado, a avaliação da qualidade do serviço deriva da comparação entre o desejado e o percebido (ZEITHAML; BITNER, 2003).

\subsection{Falhas e reclamações em serviços}

A inabilidade das organizações em satisfazer os clientes pode gerar dois mecanismos de reação: a migração para outro fornecedor de serviço ou a expressão do descontentamento via reclamação (ANDREASSEN, 2000; MICHEL; MEUTER, 2008).

A satisfação dos clientes pode estar relacionada a falhas no sistema de prestação de serviço. Tais falhas trazem uma carga extra de comunicação para o pessoal da linha de frente. Para Lovelock e Wright (2004), a equipe de linha de frente - assim como atores - desempenha papéis apoiados por uma equipe de bastidores; são as pessoas que entram em contato diretamente com o cliente e regras de conduta podem ser essenciais para melhorar a entrega do serviço, aumentar a produtividade e reforçar as percepções dos clientes. Falhas em serviço, contudo, fornecem uma oportunidade única para o pessoal da linha de frente demonstrar inovação e flexibilidade na sua reparação. Fitzsimmons e Fitzsimmons (2005) e Bateson e Hoffman (2001) apontam três categorias de falhas em serviços: (i) serviço indisponível; (ii) desempenho lento, e (iii) serviço inaceitável não atendendo os padrões.

Além das categorias de falhas apontadas, a organização de serviço necessita considerar os motivos das reclamações. 0 Quadro 1 sintetiza os tipos de reclamações e os motivos das reclamações, segundo Zeithaml e Bitner (2003) e Bateson e Hoffman (2001).

0 papel e a atitude do pessoal da linha de frente são fundamentais ao se perceber a falha no serviço. Foi constatado, em uma pesquisa citada por Bateson e Hoffman (2001), que 86\% dos clientes têm pelo menos um relato de incidente ocorrido há mais de cinco anos que os deixaram tão aborrecidos a ponto de nunca mais "entrar naquela loja ou comprar aquela marca”. Na mesma pesquisa, observou-se 
Quadro 1. Tipos de reclamações e motivos da reclamações.

\begin{tabular}{|c|l|}
\hline Item & \multicolumn{1}{c|}{ Descrição } \\
\hline $\begin{array}{c}\text { Tipo } \\
\text { da } \\
\text { reclamação }\end{array}$ & $\begin{array}{l}\text { Reclamação instrumental: expressa com o propósito de alterar um estado indesejável. 0 queixoso espera } \\
\text { que o funcionário da linha de frente e/ou empresa corrija a situação. Constitui uma pequena parte das } \\
\text { reclamações que são expressas. } \\
\text { Reclamação não instrumental: são expressa sem nenhuma expectativa de que o estado indesejável seja } \\
\text { modificado. Em reclamações não-instrumentais a resposta não é tão clara e direta. }\end{array}$ \\
\hline & $\begin{array}{l}\text { a) as reclamações têm o papel de "válvula de escape" e permitem que o queixoso dê vazão à sua frustração; } \\
\text { b) reclamar funciona como um mecanismo para o queixoso recuperar um certo controle, especialmente } \\
\text { quando ele consegue influenciar a avaliação que outras pessoas fazem da fonte de queixa; }\end{array}$ \\
c) as pessoas reclamam para pedir solidariedade e testar o consenso da reclamação, validando a avaliação \\
subjetiva do queixoso de eventos que levaram à reclamação; \\
das \\
d) os queixosos reclamam para provocar sensação e pode parecer que os padrões e as expectativas do \\
queixoso são mais altos do que daqueles que não reclamam; \\
e) os consumidores podem reclamar para reaver ou recuperar uma perda econômica, ou para que o serviço \\
seja executado novamente, podendo tomar medidas legais para que ocorra o reembolso. Por outro lado, \\
os custos envolvidos com os procedimentos de reclamações dos clientes, como realizar um telefonema, \\
escrever uma correspondência ou realizar uma reclamação verbal ou até mesmo o custo psicológico de \\
enfrentar um confronto pessoal desagradável ou estressante com o prestador de serviço podem impedir \\
que o cliente reclame.
\end{tabular}

que mais de três quartos dos informantes indicaram que haviam se envolvido em comunicações boca a boca negativas sobre o incidente; somente 53\% dos clientes fizeram reclamações à loja, apesar de 100\% terem procurado outras empresas.

Com efeito, toda empresa deveria encorajar seus clientes a reclamar. Clientes que reclamam estão dizendo à empresa que ela tem problemas operacionais ou gerenciais que precisam ser corrigidos. Oferecem à empresa, dessa forma, uma chance de restabelecer a satisfação do cliente. Quem reclama, segundo Bateson e Hoffman (2001), tem mais probabilidade de voltar a fazer negócios com a empresa do que quem não reclama. Para os Autores, muitos clientes simplesmente não reclamam por não se sentirem adequadamente qualificados para expressar uma reclamação ou por terem medo de não possuir o conhecimento necessário para avaliar a qualidade do serviço. Podem, ainda, ver a reclamação como perda de tempo e energia ou não acreditar que qualquer coisa positiva possa ocorrer a seu favor ou de outros que venham a se basear em suas ações. Em outras situações, muitas vezes, não sabem como reclamar, pois não compreendem o processo de reclamação.

Os clientes, quando despendem tempo e esforços para reclamar, em geral possuem altas expectativas (ZEITHAML e BITNER, 2003). Eles esperam ser ajudados rapidamente, ser recompensados por seu infortúnio e pelo inconveniente de terem tido contratempos. Além disso, esperam ser tratados de forma gentil durante o processo. Tais aspectos reforçam a importância de se estabelecer um processo de reclamação eficiente.

\subsection{Recuperação do serviço}

A recuperação de serviço refere-se às ações tomadas pelo prestador de serviço em resposta a uma falha no serviço (GRÖNROSS, 1988 apud MICHEL, 2001). Gerenciar reclamações baseia-se nas reclamações dos clientes que podem ser disparadas por uma falha no serviço. No entanto, visto que muitos clientes insatisfeitos são relutantes em reclamar, a recuperação do serviço objetiva resolver problemas: (i) durante o encontro do serviço, antes de o cliente reclamar, ou (ii) logo após o encontro de serviço, caso o cliente tenha ficado insatisfeito. Tanto a recuperação de serviço como o gerenciamento das reclamações são considerados como estratégias de retenção de clientes.

Solucionar efetivamente os problemas dos clientes gera um impacto positivo sobre a satisfação, a fidelidade e o desempenho operacional do cliente. Destaca-se que os clientes que enfrentam falhas na experiência de serviço, mas que ficam posteriormente satisfeitos pelos esforços de recuperação empreendidos pela empresa, serão mais fiéis do que aqueles cujos problemas não foram resolvidos (ZEITHAML e BITNER, 2003; HUANG, 2008). Tais aspectos reforçam a importância de uma estratégia eficaz de recuperação de serviços. Uma estratégia de recuperação de serviço bem projetada e bem documentada também proporciona informação que pode ser usada para melhorar o serviço como parte de um esforço contínuo de aperfeiçoamento. Pelos ajustes nos processos dos serviços, nos sistemas e nos resultados, baseando-se no aprendizado das experiências de recuperação de serviços, as empresas 
aumentam a probabilidade de "fazer a coisa certa já na primeira vez". Além do mais, reduzem-se os custos das falhas e aumenta-se a satisfação inicial do cliente (BERRY; PARASURAMAN, 1992 apud HOCUTT; BOWERS; DONAVAN, 2006).

0 Quadro 2 apresenta as estratégias de recuperação de serviço propostas por Bateson e Hoffman (2001), Zeithaml e Bitner (2003), Mattila e Cranage (2005) e Simons Jr. (2004) e as etapas do processo de recuperação propostas por Johnston e Michel (2008).

Johnston e Michel (2008) propõem que os resultados decorrentes da recuperação do serviço envolvam: (i) recuperação do cliente (por exemplo, clientes satisfeitos com o modo pelo qual a falha foi solucionada têm mais chance de se envolver em comunicação boca a boca positivo); (ii) melhorias no processo de recuperação, gerando mais eficiência e menos complexidade, e (iii) recuperação dos funcionários, como menos estresse devido a atitudes positivas na relação funcionário e trabalho, o que pode resultar em menos absenteísmo e rotatividade.

\subsection{Melhoria da qualidade em serviços}

A gestão da qualidade - enquanto conceito teórico e prática gerencial - foi desenvolvida na manufatura (LAGROSEN S.; LAGROSEN Y., 2003).
Para Behara e Gudersen (2001) e Sureschchandar RAJENDRAN; ANANTHARAMAN, (2001), iniciativas relacionadas à gestão da qualidade estão se tornando representativas em serviços. As teorias e conceitos adotados por empresas de serviços normalmente seguem os pressupostos apresentados por Deming, Juran, Crosby e outros expertos da qualidade e os modelos sugeridos pelo Malcolm Baldrige ou - no caso do Brasil -pelo Prêmio Nacional da Qualidade.

Os achados de Prajogo (2005) indicam que não há diferenças significativas quanto ao uso e ao método de uso das práticas relativas ao Gerenciamento da Qualidade Total (TQM) na manufatura e no serviço. Por outro lado, Huq (2005) salienta que identificou, em seus estudos, muitos mais casos de fracasso na implementação do TQM em serviços do que casos de sucesso. 0 Autor atribui esse fato não ao TQM em si, mas a outros fatores, como comprometimento da alta gerência, não definição e não implementação de soluções definitivas para as falhas em serviços, e falta de foco na prevenção.

No contexto apresentado, Johnston e Michel (2008) também reforçam a importância de gerenciar a qualidade total do serviço tendo como prioridade evitar que as falham ocorram; ademais, faz-se necessário o uso das informações acerca das falhas como meio para alavancar melhorias nos processos. Os Autores sugerem que o processo de melhoria tenha quatro estágios: (i) coleta de dados sobre

Quadro 2. Estratégias de recuperação de serviço e etapas do processo de recuperação do serviço.

\begin{tabular}{|c|c|}
\hline Item & Descrição \\
\hline $\begin{array}{l}\text { Estratégia de } \\
\text { recuperação } \\
\text { de serviço }\end{array}$ & $\begin{array}{l}\text { Foco inicial: faça certo da primeira vez. } \\
\text { a) assegurar-se de que o serviço esteja livre de falhas, adotando os princípios da qualidade total e usando } \\
\text { as ferramentas da qualidade apropriadas; } \\
\text { b) acolher e incentivar as reclamações; } \\
\text { c) agir rapidamente, lembrando que os clientes querem pessoas que ouçam seus problemas; isso implica } \\
\text { em capacitar e em dar poder aos funcionários da linha de frente; } \\
\text { d) tratar os clientes com justiça em termos do tratamento, do processo pelo qual a recuperação dos } \\
\text { serviços é feita e em termos de tratamento interpessoal que recebem; } \\
\text { e) aprender com as experiências de recuperação, acompanhando os esforços e soluções aplicados na } \\
\text { recuperação do serviço, buscando visualizar problemas sistemáticos ocorridos na prestação do serviço; } \\
\text { f) aprender com os clientes perdidos, por meio de pesquisas de mercado conduzidas formalmente com o } \\
\text { propósito de descobrir as razões para os clientes terem deixado a empresa; } \\
\text { g) voltar a "fazer a coisa certa”, assegurando de que o processo de melhoria contínua está efetivamente } \\
\text { implementado; } \\
\text { h) manter os clientes informados sobre o andamento do processo de recuperação do serviço; } \\
\text { i) fazer avaliações analíticas dos resultados do processo de recuperação. }\end{array}$ \\
\hline $\begin{array}{l}\text { Etapas do } \\
\text { processo de } \\
\text { recuperação } \\
\text { do serviço }\end{array}$ & $\begin{array}{l}\text { a) reconhecer que o problema ocorreu; } \\
\text { b) empatia - entender o problema sob o ponto de vista do cliente; } \\
\text { c) desculpar-se; } \\
\text { d) reconhecer o problema; } \\
\text { e) corrigir o problema; } \\
\text { f) assegurar que não ocorrerá novamente; } \\
\text { g) providenciar uma compensação ao cliente proporcional à gravidade e à seriedade do problema. }\end{array}$ \\
\hline
\end{tabular}


reclamações e os procedimentos operacionais de recuperação para que informações acerca de áreas problemáticas estejam disponíveis aos gestores; (ii) análise dos dados para que seja possível identificar os problemas e estabelecer prioridades; (iii) análise dos custos e outras implicações para direcionar a melhoria dos processos, e (iv) melhoria dos processos, onde for apropriado, certificando-se da efetiva implementação e avaliando os impactos.

\subsection{Síntese do referencial teórico}

A análise do referencial teórico possibilita a identificação de variáveis relevantes para a compreensão do processo de recuperação dos serviços, decorrente das reclamações dos clientes. As variáveis a serem investigadas neste trabalho, sob a perspectiva de serviços de massa, loja de serviços e serviços profissionais, extraídas no referencial teórico, são apresentadas no Quadro 3.

\section{Delineamento da investigação}

A pesquisa envolve a obtenção de dados descritivos de modo a compreender os fenômenos segundo a perspectiva dos participantes da situação em estudo; a partir desses dados e sustentada por teorias e princípios convergentes com a busca da melhoria dos processos, esta pesquisa procura identificar as lacunas nas práticas das organizações e os parâmetros considerados relevantes pelas mesmas.

A pesquisa é exploratória e a estratégia escolhida é o estudo de caso. Segundo Yin (2001), essa técnica é indicada quando se examinam acontecimentos contemporâneos e não se podem manipular ou influenciar comportamentos relevantes. Além disso, objetiva-se compreender "como" as empresas se posicionam em relação à implementação dos elementos avaliados. Para a compreensão de "como" um determinado fenômeno ocorre, Voss, Tsikriktsis e Frohlich (2002) sugerem o estudo de caso como técnica de pesquisa. Outro ponto que sustenta o uso do estudo de caso é o fato de a pesquisa caracterizar-se por um relacionamento próximo entre pesquisador e organizações estudadas e pela coleta de dados segundo instrumento pré-definido (roteiro para entrevista).

A questão de pesquisa que norteia o presente estudo é:

Como empresas de serviços com diferentes níveis de contato com os clientes gerenciam os processos de recuperação do serviço desencadeados a partir das reclamações?
A resposta à questão anterior objetivou:

Permitir analisar, em nível exploratório, sobre o modo como as práticas adotadas na gestão da recuperação do serviço podem ser inseridas no contexto da melhoria dos processos da organização.

0 grau de contato do cliente com o prestador de serviço foi o elemento considerado para a seleção da amostra. Busca-se analisar o processo de recuperação de serviços em empresas com diferentes niveis de contato, considerando-se as questões levantadas por Fitzsimmons J. e Fitzsimmons M. (2005) no que se refere à padronização das ações, ao uso da estrutura e ao tipo de interação da linha de frente com o cliente.

A unidade de análise é composta por três empresas de diferentes níveis de contato, seguindo a classificação de lovelock e Wright (2004), apresentada no referencial teórico. Foram consideradas: uma empresa de serviços profissionais, caracterizada por ter um alto grau de contato; uma loja de serviços, que apresenta um médio grau de contato, e uma empresa de transmissão e distribuição de energia, de baixo grau de contato. As empresas que compõem a unidade de amostra apresentam claramente as características descritas pelos Autores no que se refere ao grau de contato. Dessa forma, acredita-se que as mesmas possam representar seus estratos (baixo grau de contato, médio grau de contato e alto grau de contato).

A empresa denominada $A$, de serviços profissionais, atua em consultorias nas áreas contábil, fiscal, organizacional e reorganização empresarial. No quadro funcional, a empresa conta com trinta colaboradores, tendo cerca de duzentos clientes em carteira. A empresa tem três sócios diretores (Contábil, Jurídico e Financeiro) e um setor da qualidade, subordinado diretamente aos diretores. A função do setor da qualidade é averiguar e complementar as atividades referentes à eficiência dos serviços prestados pela empresa, assim como implantar e controlar aspectos relacionados com a gestão adequada da organização, para trazer melhorias contínuas nos processos envolvidos dentro da organização. A empresa tem como missão prestar um serviço diferenciado, participando ativamente das decisões políticas e gerenciais, utilizando-se da técnica por excelência, na busca de opções que resultem em melhores resultados e, como consequência, na satisfação dos seus clientes.

A empresa B conta com três lojas do ramo farmacêutico situadas no Estado do Rio Grande do Sul (RS), distribuindo produtos das áreas de higiene, medicamentos e perfumaria. As lojas da empresa B operam com atendimento de balcão, telefônico 
Quadro 3. Síntese das variáveis de pesquisa.

\begin{tabular}{|c|l|c|}
\hline Variáveis & \multicolumn{1}{|c|}{ Síntese } & Autores \\
\hline Atendimento & $\begin{array}{l}\text { Relaciona-se com o modo como ocorre a interface entre o prestador } \\
\text { de serviço e c cliente em serviços de baixo, médio ou alto grau de } \\
\text { contato do cliente com o pessoal da linha de frente. }\end{array}$ & $\begin{array}{c}\text { Fitzsimmons J. e } \\
\text { Fitzsimmons M. (2005), } \\
\text { Lovelock e Wright (2004) }\end{array}$ \\
\hline Relacionamento & $\begin{array}{l}\text { Refere-se ao papel e atitude do pessoal da linha de frente durante } \\
\text { os encontros de serviços. }\end{array}$ & Bateson e Hoffman (2001) \\
\hline Satisfação & $\begin{array}{l}\text { A satisfação dos clientes é decorrente da comparação entre o } \\
\text { serviço previsto e o serviço percebido. }\end{array}$ & $\begin{array}{c}\text { Zeithaml e Bitner (2003), } \\
\text { Glynn et al. (2003) }\end{array}$ \\
\hline Reclamação & $\begin{array}{l}\text { Refere-se à comunicação expressa de uma insatisfação. Ter um } \\
\text { canal de reclamação possibilita resolver problemas percebidos } \\
\text { pelos clientes e melhorar processos internos. }\end{array}$ & $\begin{array}{c}\text { Zeithaml e Bitner (2003), } \\
\text { Bateson e Hoffman (2001) }\end{array}$ \\
\hline Melhorias & $\begin{array}{l}\text { Consiste em solucionar efetivamente as falhas, percebidas ou não } \\
\text { pelos clientes. }\end{array}$ & $\begin{array}{l}\text { Refere-se ao gerenciamento da qualidade total do serviço tendo Hoffman (2001) } \\
\text { como prioridade evitar que falhas ocorram; sugere-se usar as }\end{array}$ \\
\hline informações sobre as falhas para alavancar as melhorias & Johnston e Michel (2008) \\
\hline
\end{tabular}

e tele-entrega; os clientes mantêm contato direto com atendentes e farmacêuticos; algumas ações são executadas de modo padronizado e conforme ordens pré-estabelecidas. Essas lojas estão integradas a uma rede derivada de uma associação de farmácias da região sul, que dá suporte e estabelece diretrizes e metas para as lojas afiliadas. A rede de associados, à qual pertencem as lojas da empresa $\mathrm{B}$, nasceu da necessidade de fortalecimento e união de um grupo de empresários, para fazer frente aos desafios que o mercado passou a exigir a partir da globalização da economia. Esta aliança estratégica de pequenos e médios empresários, através do associativismo, foi a resposta prática para crescer dentro de uma acirrada concorrência. Atualmente, a rede é uma das maiores redes de farmácias do Rio Grande do Sul. São mais de trezentas farmácias distribuídas por todo o Estado que trabalham de forma associada, com o objetivo de oferecer produtos e serviços diferenciados, melhores preços, variedade e qualidade dos medicamentos.

A empresa C é uma empresa de transmissão e distribuição de energia elétrica. A divisão de telecomunicação é responsável pelo atendimento ao cliente. 0 departamento de operações e manutenção dos sistemas é encarregado de planejar e implementar as ações de verificação, correção e identificação de falhas na rede, na transmissão e na distribuição de energia. A empresa de energia elétrica pesquisada foi fundada em 1943, subordinada à Secretaria de Estado dos Negócios das Obras Públicas. Em 1945, iniciou suas atividades na área de eletrificação e distribuição de energia elétrica no Rio Grande do Sul. A empresa passou por vários processos de reestruturação patrimonial e atualmente atua com as concessões para as atividades de geração hidrelétrica, transmissão de energia elétrica no Rio Grande do Sul e distribuição de eletricidade na região sul e sudeste desse Estado. Atende em torno de 72 municípios, tendo 29 postos de atendimento com um total de 2.333 funcionários na área de distribuição. Possui cerca de 1 milhão e 355 mil clientes referentes à área de cobertura da empresa e produz aproximadamente $6.287{\mathrm{GWh} . \mathrm{ano}^{-1}}^{-1}$ (dados até dezembro de 2006), beneficiando uma população de 4 milhões e 50 mil pessoas.

A coleta de evidências se baseou em entrevistas semiestruturadas com os dois gestores do setor da qualidade da empresa $A$, com o sócio diretor da empresa B e com gestores da divisão de distribuição e transmissão de energia da empresa C. Observações diretas e análise de documentos compuseram as demais fontes de evidências coletadas.

Os aspectos investigados, tanto por meio das questões semiestruturadas ou por observação direta, relacionam-se com: o atendimento ao cliente e o tipo de relacionamento mantido com o mesmo; o processo de avaliação da satisfação do cliente; o processo de reclamação; o processo de recuperação e as ações de melhorias decorrentes das reclamações, e as ações de recuperação.

\section{Estudo de caso}

0 Quadro 4 apresenta as informações obtidas para cada uma das variáveis investigadas, nas empresas A, B e C. 
Cada organização estudada pratica ações de atendimento a clientes, relacionamentos, satisfação e recebimento de reclamações julgadas necessárias para a realização de suas atividades, mantendo, também, processos de recuperação de serviços. Os processos de recuperação de serviços observados nos estudos dos casos mostram que as empresas adotam métodos e procedimentos para recuperação de seus serviços de acordo com seu segmento de atuação e sua interação com seus clientes, apresentando, conforme as políticas adotadas, formas ou maneiras diferentes para tratar os consumidores recebedores de seus serviços.

Apresenta-se, na sequência, a análise de cada um dos casos estudados no que se refere ao processo de recuperação do serviço, decorrente das reclamações.

\subsection{Análise do caso $A$}

De acordo com as informações da empresa A, o processo de recuperação de serviços não se baseia em procedimentos padronizados e rígidos: a recuperação se dá conforme as solicitações de seus clientes e de acordo com as falhas ou problemas ocorridos. Aliado a isso, por meio de flexibilidade nas ações e nos processos internos, a empresa busca tornar o cliente satisfeito e resolver o problema. Muitas vezes, ocorre a participação dos diretores em diferentes etapas dos processos de serviços, já que esses são responsáveis por um grupo ou um conjunto de áreas afins com suas competências e áreas de conhecimento.

Outro aspecto relevante é que muitos dos clientes manifestam suas insatisfações de imediato, não esperando a empresa questioná-los ou averiguar como está a satisfação e a qualidade do serviço. lsso sugere que os problemas devem ser resolvidos eficientemente e com rapidez, para não permitir que o cliente se sinta lesado e, assim, não utilize mais os serviços. Evita-se, também, o boca a boca negativo junto a clientes potenciais, já que a empresa, pela natureza de seu serviço, necessita de reconhecimento para se manter no segmento e expandir sua rede de relacionamentos de maneira consistente.

0 Quadro 5 mostra, para a empresa A, a relação da recuperação de serviços com o sistema de atendimento, relacionamento, avaliação da satisfação, reclamações e melhorias visando minimizar as falhas.

Conforme ilustrado no Quadro 5, uma dinâmica de recuperação numa situação em que há alto contato com o cliente e o mesmo participa das atividades de prestação de serviço repercute em grande impacto para ele, conforme as atividades desencadeadas pela empresa. Necessita-se, portanto, do intercâmbio de informações para que todos saibam de tudo que está ocorrendo na empresa de forma sistêmica, já que cada setor interage constantemente com o outro.

Para melhor entendimento, a Figura 1 apresenta, de maneira ilustrativa, os processos envolvidos na recuperação de um serviço com alto nível de contato, tomando-se como referência aquele observado na empresa A. Pelo contato constante e frequente da diretoria e/ou colaboradores da empresa A, com seus clientes realizando o feedback das informações, os clientes fornecem informações sobre a recuperação dos serviços e indicam se a mesma foi satisfatória e atendeu o que se esperaria para a situação. Dessa forma, a diretoria e/ou colaboradores realimentam o processo de recuperação e, posteriormente, as ações de melhorias nos processos da empresa.

Observa-se que o cliente é muito suscetível ao comportamento da organização. Pelo fato de se estabelecer uma relação de confiança entre cliente e empresa, a zona de tolerância que divide o serviço aceitável do serviço desejado tende a se tornar mais abrangente, já que o cliente expressa suas insatisfações e reclamações sempre que julga necessário. Permite-se, com isso, que a empresa tome as medidas de

\subsection{Análise do caso B}

$\mathrm{Na}$ empresa de varejo, as ações de recuperação estão atreladas aos treinamentos recebidos pelos funcionários e às informações coletadas por um sistema de gestão de relacionamentos, bem como aos resultados das pesquisas de satisfação realizadas com o intuito de captar insatisfações, problemas, falhas ou reclamações.

Como se trata de uma empresa de varejo com médio grau de contato com seus clientes, o relacionamento com os consumidores acaba ocorrendo pela procura dos mesmos por melhores condições de preços, produtos, ofertas e tratamento adequado aos seus desejos de consumo.

Nota-se que a organização procura trazer o cliente o mais próximo possível da rede, a fim de manter um contato mais transparente e identificar os aspectos relevantes para o cliente em relação ao atendimento e à recuperação dos serviços. A empresa entende que deve atender os níveis de expectativas adequadamente, pois qualquer erro suscetivel de insatisfação pode acarretar na desistência do consumidor em utilizar os serviços oferecidos, 
Quadro 4 . Informações sobre aspectos investigados nas empresas A, B e C.

\begin{tabular}{|c|c|c|c|}
\hline & Caso A & Caso B & Caso C \\
\hline Atendimento & $\begin{array}{l}\text { Empresa de alto grau de } \\
\text { contato; cliente com grau } \\
\text { de "amizade". atendimento } \\
\text { telefônico, pessoalmente e por } \\
\text { e-mail; informativos mensais para } \\
\text { esclarecimento do andamento de } \\
\text { processos envolvendo o cliente; } \\
\text { todos os setores trabalham } \\
\text { unidos; há fluxo de informações } \\
\text { contínuo entre os setores. }\end{array}$ & $\begin{array}{l}\text { Empresa de médio grau de } \\
\text { contato; o cliente interage com a } \\
\text { empresa mediante ações regulares; } \\
\text { colaboradores com conhecimento } \\
\text { técnico; atendimento de balcão } \\
\text { e telefônico; treinamentos } \\
\text { realizados para capacitação; } \\
\text { uso de software de gestão de } \\
\text { relacionamento com o cliente; } \\
\text { controle das informações obtidas. }\end{array}$ & $\begin{array}{l}\text { Empresa com baixo grau de contato; } \\
\text { metas de desempenho estabelecidas } \\
\text { por órgão regulador; dois tipos de } \\
\text { atendimento: comercial e emergencial; } \\
\text { formas de atendimento: telefone, } \\
\text { site ou comparecimento do cliente } \\
\text { na empresa; treinamentos regulares } \\
\text { e com periodicidades definida; } \\
\text { encaminhamento das solicitações para } \\
\text { setores responsáveis pela execução. }\end{array}$ \\
\hline Relacionamento & $\begin{array}{l}\text { Primeiro contato com os clientes } \\
\text { feito pela própria diretoria; } \\
\text { contatos periódicos com os } \\
\text { clientes durante a execução } \\
\text { do projeto; o cliente participa } \\
\text { continuamente da prestação do } \\
\text { serviço. }\end{array}$ & $\begin{array}{l}\text { Atendimento a pessoa física e } \\
\text { convênios para pessoa jurídica; } \\
\text { visitas às empresas conveniadas; } \\
\text { alta concorrência, necessitando } \\
\text { fortes ações de manutenção de } \\
\text { clientes. }\end{array}$ & $\begin{array}{l}\text { Relacionamento sem realização } \\
\text { de visitas aos clientes de caráter } \\
\text { comercial; não necessitam captar } \\
\text { clientes; os clientes que solicitam o } \\
\text { serviço; visitas técnicas realizadas no } \\
\text { caso de atendimento emergencial. }\end{array}$ \\
\hline Satisfação & $\begin{array}{l}\text { Não adota pesquisas de } \\
\text { satisfação; cliente expressa } \\
\text { sua insatisfação de imediato; } \\
\text { comunica sua insatisfação à } \\
\text { empresa ou ao setor específico; } \\
\text { feedback dos clientes obtidos } \\
\text { pela diretoria. }\end{array}$ & $\begin{array}{l}\text { Cadastro de clientes com auxílio } \\
\text { de softwaregerencial; formulários } \\
\text { aplicados nas lojas para captar } \\
\text { possíveis insatisfações; contato } \\
\text { para lembrar o cliente para } \\
\text { compra de medicamentos de uso } \\
\text { contínuo. }\end{array}$ & $\begin{array}{l}\text { Pesquisas de satisfação realizadas } \\
\text { conforme definido pelo órgão regulador; } \\
\text { a empresa realiza pesquisas mais } \\
\text { restritas; usa os dados e informações } \\
\text { das pesquisas para tomada de decisão. }\end{array}$ \\
\hline Reclamações & $\begin{array}{l}\text { Reclamações recebidas por } \\
\text { telefone, e-mailou pessoalmente; } \\
\text { cliente reclama de imediato, } \\
\text { solicitando reparação; não } \\
\text { utiliza nenhuma ferramenta para } \\
\text { gerenciar as reclamações; }\end{array}$ & $\begin{array}{l}\text { Capta reclamações por formulários } \\
\text { ou atendimento telefônico } \\
\text { ou pessoal; uso de software } \\
\text { para dar suporte ao cadastro } \\
\text { de reclamações; não adota } \\
\text { indicadores para este item; resolve } \\
\text { individualmente cada reclamação. }\end{array}$ & $\begin{array}{l}\text { Reclamações consideradas "urgências": } \\
\text { por telefone; demais reclamações: por } \\
\text { atendimento telefônico e ouvidoria; } \\
\text { registram-se as reclamações com } \\
\text { auxilio de software gerencial. }\end{array}$ \\
\hline Recuperação & $\begin{array}{l}\text { Recuperação dos serviços } \\
\text { feita com auxílio da diretoria; } \\
\text { autonomia dos funcionários } \\
\text { para resolução de problemas; } \\
\text { ações de recuperação baseiam- } \\
\text { se em informações obtidas } \\
\text { nas visitas aos clientes; ações } \\
\text { ocorrem imediatamente com } \\
\text { o recebimento da solicitação } \\
\text { por parte do cliente, pelo setor } \\
\text { responsável; implementação } \\
\text { de melhorias em casos de } \\
\text { reclamações reincidentes ou } \\
\text { crônicas; não utiliza indicadores } \\
\text { para recuperação; monitoramento } \\
\text { dos processos de recuperação. }\end{array}$ & $\begin{array}{l}\text { Considera a necessidade de } \\
\text { recuperação imediata; adota um } \\
\text { "pós-reclamação" para averiguar } \\
\text { a recuperação dos serviços; entra } \\
\text { em contato com o cliente para } \\
\text { obter um feedback e promover } \\
\text { melhorias futuras; controle } \\
\text { diário de medicamentos; cursos } \\
\text { ministrados constantemente } \\
\text { para aperfeiçoamento dos } \\
\text { colaboradores; autonomia dos } \\
\text { funcionários de acordo com a } \\
\text { hierarquia; funcionários tomam } \\
\text { medidas de recuperação conforme } \\
\text { ordens e treinamentos recebidos. }\end{array}$ & $\begin{array}{l}\text { Recuperação dos serviços conforme } \\
\text { definido pelos órgãos reguladores; } \\
\text { utilização de normas e métodos } \\
\text { definidos para a adequação da } \\
\text { prestação de serviço; utiliza indicadores } \\
\text { de desempenho pré-definidos; } \\
\text { trabalha com a recuperação em } \\
\text { comunidade de clientes ou individuais; } \\
\text { treinamento rigido e completo devido } \\
\text { ao exercício de atividades de risco; } \\
\text { ações de recuperação diferenciadas } \\
\text { somente para grandes clientes } \\
\text { (indústrias representativas nos ganhos } \\
\text { da empresa). }\end{array}$ \\
\hline Melhorias & $\begin{array}{l}\text { Reuniões semanais para efetuar } \\
\text { e organizar ações potenciais de } \\
\text { melhorias; discutem-se aspectos } \\
\text { geradoresdeinsatisfação; exposição } \\
\text { de reclamações recebidas com } \\
\text { maior frequência para canalizar } \\
\text { esforços de melhorias. }\end{array}$ & $\begin{array}{l}\text { Pesquisas de satisfação com o } \\
\text { cliente; formulários com campo } \\
\text { para sugestões de melhorias; } \\
\text { reuniões quinzenais com equipe } \\
\text { operacional; aspectos como } \\
\text { reclamações frequentes, vendas e } \\
\text { atendimento são abordados nas } \\
\text { reuniões. }\end{array}$ & $\begin{array}{l}\text { Reuniões periódicas com os diretores } \\
\text { de cada área; setor de atendimento: } \\
\text { históricos de reclamações e nível de } \\
\text { atendimento adotado; reuniões com } \\
\text { os órgãos que realizam as pesquisas de } \\
\text { satisfação; indicadores de desempenho } \\
\text { como base para ações de melhorias. }\end{array}$ \\
\hline
\end{tabular}




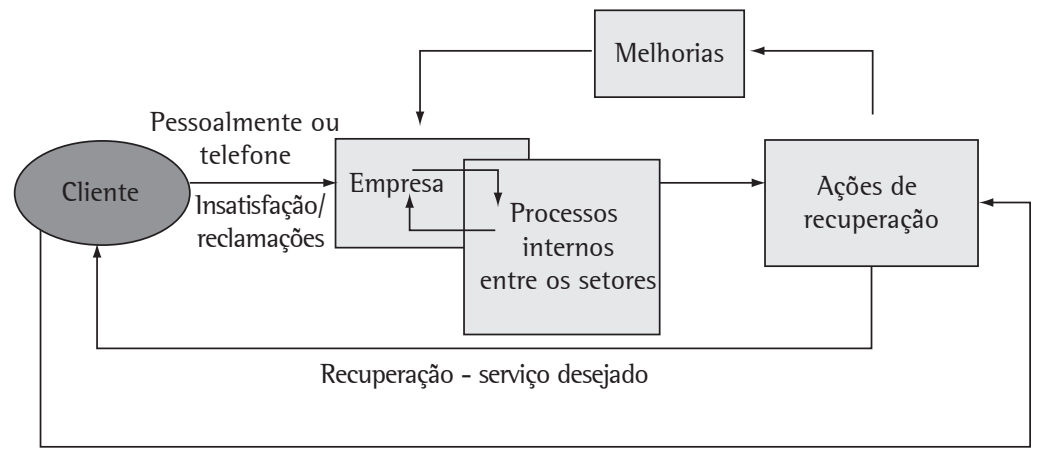

Feedback pela diretoria ou colaboradores

Figura 1. Processo de recuperação de serviço com alto contato.

Quadro 5. Relação entre os fatores de recuperação e itens relacionados.

\begin{tabular}{|c|c|c|c|c|c|}
\hline \multicolumn{6}{|c|}{ Recuperação } \\
\hline Item & Atendimento & Relacionamento & Satisfação & Reclamações & Melhorias \\
\hline $\begin{array}{l}\text { Obtenção } \\
\text { de } \\
\text { informação }\end{array}$ & $\begin{array}{c}\text { Telefônico, } \\
\text { pessoalmente ou } \\
e \text {-mail, permitindo } \\
\text { retorno ao } \\
\text { solicitante por parte } \\
\text { do colaborador }\end{array}$ & $\begin{array}{l}\text { Reuniões com a } \\
\text { diretoria; eventos } \\
\text { com clientes }\end{array}$ & $\begin{array}{l}\text { Visitas da diretoria; } \\
\text { visitas técnicas } \\
\text { durante os projetos }\end{array}$ & $\begin{array}{l}\text { Pessoalmente, ou } \\
\text { telefônico com } \\
\text { a correção do } \\
\text { problema específico }\end{array}$ & $\begin{array}{c}\text { Através de } \\
\text { informações } \\
\text { coletadas nas } \\
\text { visitas aos clientes }\end{array}$ \\
\hline $\begin{array}{l}\text { Contato } \\
\text { com } \\
\text { clientes }\end{array}$ & $\begin{array}{l}\text { Feito por telefone } \\
\text { ou pessoalmente }\end{array}$ & $\begin{array}{l}\text { Preservação da } \\
\text { confiança do } \\
\text { relacionamento }\end{array}$ & $\begin{array}{l}\text { Busca realizar } \\
\text { atividades com } \\
\text { resolução rápida e } \\
\text { imediata }\end{array}$ & $\begin{array}{l}\text { Recebe as } \\
\text { reclamações sem } \\
\text { restrições por parte } \\
\text { do cliente }\end{array}$ & $\begin{array}{c}\text { Reuniões semanais } \\
\text { com a diretoria e } \\
\text { colaboradores }\end{array}$ \\
\hline $\begin{array}{l}\text { Eficiência } \\
\text { das } \\
\text { atividades }\end{array}$ & $\begin{array}{l}\text { Gera alto impacto } \\
\text { nas decisões e } \\
\text { imagem da empresa }\end{array}$ & $\begin{array}{l}\text { Através de ações } \\
\text { conjuntas entre } \\
\text { os colaboradores }\end{array}$ & $\begin{array}{c}\text { Por meio de } \\
\text { reuniões periódicas } \\
\text { com representantes } \\
\text { de cada área, } \\
\text { através de medidas } \\
\text { estipuladas }\end{array}$ & $\begin{array}{c}\text { Ações desencadeadas } \\
\text { em conjunto } \\
\text { com diretores e } \\
\text { responsáveis por } \\
\text { áreas }\end{array}$ & $\begin{array}{l}\text { Sob grande } \\
\text { responsabilidade } \\
\text { dos colaboradores }\end{array}$ \\
\hline $\begin{array}{l}\text { Controle } \\
\text { dos } \\
\text { processos }\end{array}$ & $\begin{array}{c}\text { Não possui sistema } \\
\text { de controle }\end{array}$ & $\begin{array}{l}\text { Apenas com } \\
\text { informações } \\
\text { obtidas }\end{array}$ & $\begin{array}{l}\text { Informativos } \\
\text { mensais para os } \\
\text { clientes e pareceres } \\
\text { feitos a diretoria }\end{array}$ & $\begin{array}{l}\text { Comunicação } \\
\text { entre setores } \\
\text { até a diretoria, } \\
\text { sem o registro } \\
\text { documentado }\end{array}$ & $\begin{array}{c}\text { Controlado pela } \\
\text { diretoria e setor de } \\
\text { qualidade }\end{array}$ \\
\hline Empenho & $\begin{array}{l}\text { Conhecimento } \\
\text { de todos de suas } \\
\text { obrigações e } \\
\text { atividade }\end{array}$ & $\begin{array}{l}\text { Participação } \\
\text { do cliente nos } \\
\text { processos de } \\
\text { serviços }\end{array}$ & $\begin{array}{l}\text { Necessidade de } \\
\text { integração de todos }\end{array}$ & $\begin{array}{l}\text { Recebe sempre } \\
\text { que surge uma } \\
\text { falha, necessitando } \\
\text { imediata correção }\end{array}$ & $\begin{array}{l}\text { Situações que } \\
\text { apresentam } \\
\text { maior número de } \\
\text { reclamações }\end{array}$ \\
\hline
\end{tabular}

gerando grande impacto sob a percepção do cliente. Portanto, para uma recuperação eficaz de uma falha ou insatisfação, a organização adota meios de potencializar a obtenção de informações dos clientes para realizar e focar os esforços de recuperação, com o objetivo de atender as expectativas dos clientes, com ações de melhorias, evitando que migrem para outra empresa do ramo.

A Figura 2 ilustra alguns fatores influenciadores no atendimento das expectativas e a recuperação eficaz de falhas, considerando-se o exposto pela empresa B.
Pode-se notar que os fatores potencializadores de recuperação estão ligados diretamente com o treinamento adequado, a capacitação técnica, o atendimento rápido, o histórico das reclamações para ações de melhorias e o controle adequado dos produtos vendidos. Agregadas a isso, as ações de recuperação envolvem as pesquisas de satisfação realizadas pela rede, com auxílio de um sistema gerencial de relacionamento com o cliente para armazenar informações relevantes quanto às preferências dos clientes e às reclamações feitas pelos 
mesmos. Dessa forma, possibilitam-se o controle e o conhecimento das ações a serem desenvolvidas para a melhoria contínua dos serviços.

0 impacto dos serviços oferecidos é de extrema importância e decisivo no que diz respeito ao caráter decisório do consumidor, pois o mesmo considera três aspectos importantes e complementares para se sentir satisfeito com a recuperação eficaz nesse segmento: (i) agilidade em solucionar problemas e fornecer informações; (ii) comprometimento, e (iii) atendimento adequado, de acordo com suas reais necessidades.

No contexto analisado, o médio grau de contato permite que a empresa adote políticas e

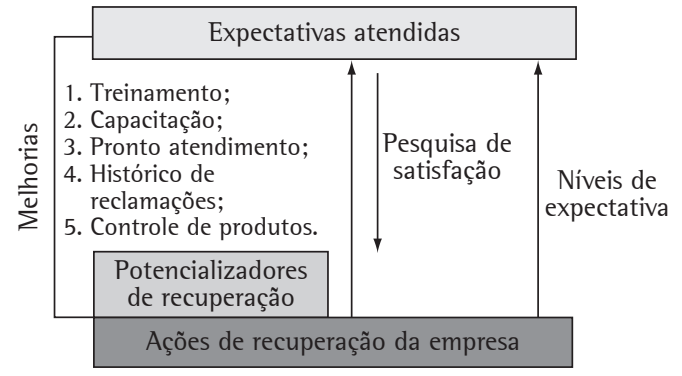

Figura 2. Impacto dos esforços de recuperação em empresa de médio contato. procedimentos com tendência mais padronizada. Ressalta-se, no entanto, a dependência das pesquisas e dos métodos para captar reclamações e possiveis insatisfações, e para adequar a oferta de produtos às necessidades intrínsecas que fazem parte do recebedor de serviços. A alternativa utilizada pela empresa B foi a adoção de rígido programa de treinamentos e qualificação dos colaboradores e a utilização de um sistema de gestão de relacionamentos como forma de suporte para a tomada de decisão para a recuperação. 0 Quadro 6 apresenta os itens relacionados com a recuperação e como se procedem às ações de melhorias.

Com estas observações, permite-se ajustar e reduzir a distância entre o serviço adequado e o serviço desejado pelo cliente. Tal aspecto é considerado relevante pelo fato da grande concorrência do segmento; os consumidores migram para outras empresas que oferecem os mesmos serviços caso se sintam descontentes com o mau atendimento ou com algum aspecto gerador de desconforto. A zona de tolerância, para esse caso, fica muito reduzida ou estreita (limitada), forçando para que as ações de recuperação sejam realizadas com grande eficiência, não deixando margem para novas correções posteriores, que poderiam acarretar na perda de clientes por descontentamento.

Quadro 6. Itens de influência para a recuperação eficaz e melhorias.

\begin{tabular}{|c|c|c|c|c|c|}
\hline \multicolumn{6}{|c|}{ Recuperação } \\
\hline Item & Atendimento & Relacionamento & Satisfação & Reclamações & Melhorias \\
\hline $\begin{array}{l}\text { Obtenção } \\
\text { de } \\
\text { informação }\end{array}$ & $\begin{array}{l}\text { Atendimento } \\
\text { balcão e } \\
\text { telefônico }\end{array}$ & $\begin{array}{c}\text { Visitas dos } \\
\text { diretores aos } \\
\text { clientes maiores }\end{array}$ & $\begin{array}{l}\text { Pesquisas } \\
\text { realizadas nas } \\
\text { lojas }\end{array}$ & $\begin{array}{l}\text { Questionários, } \\
\text { pessoalmente } \\
\text { pelo cliente e } \\
\text { telefônico }\end{array}$ & $\begin{array}{c}\text { Pesquisas de satisfação, } \\
\text { software CRM e contato } \\
\text { do colaborador por } \\
\text { telefone }\end{array}$ \\
\hline $\begin{array}{l}\text { Contato } \\
\text { com } \\
\text { clientes }\end{array}$ & $\begin{array}{c}\text { Pessoalmente ou } \\
\text { telefônico }\end{array}$ & $\begin{array}{l}\text { Diretoria com } \\
\text { os clientes mais } \\
\text { representativos. } \\
\text { Funcionários para } \\
\text { público em geral }\end{array}$ & $\begin{array}{l}\text { Questionários } \\
\text { distribuídos na } \\
\text { rede e contato } \\
\text { telefônico }\end{array}$ & $\begin{array}{l}\text { Contato dos } \\
\text { colaboradores } \\
\text { com o cliente por } \\
\text { telefone }\end{array}$ & $\begin{array}{c}\text { Procura lembrar o } \\
\text { cliente de comprar } \\
\text { medicamentos de uso } \\
\text { contínuo }\end{array}$ \\
\hline $\begin{array}{l}\text { Eficiência } \\
\quad \text { das } \\
\text { atividades }\end{array}$ & $\begin{array}{l}\text { Atividades } \\
\text { executadas de } \\
\text { acordo com } \\
\text { procedimentos } \\
\text { orientados }\end{array}$ & $\begin{array}{l}\text { Tornar o contato } \\
\text { com o cliente } \\
\text { o mais próximo } \\
\text { possível da rede } \\
\text { de lojas }\end{array}$ & $\begin{array}{l}\text { Esforços na } \\
\text { realização de } \\
\text { pesquisas e } \\
\text { utilização de } \\
\text { software de } \\
\text { relacionamento }\end{array}$ & $\begin{array}{l}\text { Atividades } \\
\text { realizadas com } \\
\text { auxílio de sistema } \\
\text { gerencial, junto } \\
\text { com as pesquisas }\end{array}$ & $\begin{array}{l}\text { Informações } \\
\text { registradas no sistema } \\
\text { gerencial, histórico } \\
\text { das reclamações e } \\
\text { treinamentos dos } \\
\text { funcionários }\end{array}$ \\
\hline $\begin{array}{l}\text { Controle } \\
\text { dos } \\
\text { processos }\end{array}$ & $\begin{array}{c}\text { Feito pelos } \\
\text { gerentes, com } \\
\text { auxílio de software } \\
\text { de gestão }\end{array}$ & $\begin{array}{l}\text { Controle feito } \\
\text { pelos diretores } \\
\text { e gerentes e } \\
\text { supervisores }\end{array}$ & $\begin{array}{c}\text { Pesquisas, } \\
\text { questionários e } \\
\text { sistema gerencial } \\
\text { de relacionamento }\end{array}$ & $\begin{array}{l}\text { Registro e } \\
\text { histórico de } \\
\text { reclamações }\end{array}$ & $\begin{array}{c}\text { Reuniões quinzenais em } \\
\text { cada loja entre gerentes } \\
\text { e supervisores, junto } \\
\text { com a diretoria }\end{array}$ \\
\hline Empenho & $\begin{array}{l}\text { Atendimento das } \\
\text { solicitações com } \\
\text { auxílio de sistema } \\
\text { gerencial }\end{array}$ & $\begin{array}{l}\text { Esforço para } \\
\text { captar e manter } \\
\text { clientes maiores } \\
\text { (conveniados) }\end{array}$ & $\begin{array}{l}\text { Empregado } \\
\text { com base nas } \\
\text { informações } \\
\text { obtidas com as } \\
\text { pesquisas }\end{array}$ & $\begin{array}{l}\text { Captar o maior } \\
\text { número de } \\
\text { informações } \\
\text { possíveis }\end{array}$ & $\begin{array}{l}\text { Melhorias baseadas em } \\
\text { histórico de reclamações } \\
\text { e insatisfações } \\
\text { coletadas. Sendo } \\
\text { expostas em reuniões }\end{array}$ \\
\hline
\end{tabular}




\subsection{Análise do caso $C$}

Na empresa C, verifica-se uma maior padronização dos processos internos da empresa, enfatizados pelas diretrizes e normas estabelecidas por órgãos de fiscalização, que normalizam e controlam as atividades da empresa. Sendo assim, permite-se ter uma garantia mais definitiva da qualidade dos serviços prestados e, consequentemente, a satisfação dos clientes.

Essa organização, por apresentar um baixo grau de contato com seu consumidor, realiza os esforços de recuperação baseados nas pesquisas de satisfação realizadas pelos órgãos regulamentadores e no histórico de reclamações registradas e obtidas pelo setor de atendimento ao cliente. Os esforços de recuperação e, consequentemente, as ações desencadeadas, são planejados e executados pelo setor responsável por uma determinada falha. Ressalta-se, também, que a recuperação se dá, na maioria das vezes, em caráter emergencial, em que é necessária a realização de reparos, devendo ser cumpridos os prazos e tempos máximos estipulados por normas regularizadas aplicadas ao setor de energia elétrica.

A recuperação é baseada em procedimentos pré-determinados e rígidos, nos quais muitas ações são fiscalizadas e sofrem controle dos órgãos reguladores. Para isso, os funcionários da linha de frente passam por constantes treinamentos específicos com sua área de atuação, não deixando muita margem para flexibilização de atividades e autonomia dos funcionários, independentemente de estes serem de nível técnico-operacional ou de nível administrativo.

Para melhor compreensão, a Figura 3 mostra a relação das ações de recuperação com as reclamações e como a melhoria é implementada na organização.
As ações de recuperação - geradas a partir de uma reclamação ou solicitação de serviço de reparo - são recebidas pelo setor de atendimento e encaminhadas para o setor específico, encarregado de realizar as ações devidas.

0 Quadro 7 apresenta as características do serviço com itens impactantes nas ações de recuperação e melhorias contínuas na empresa.

Com efeito, os esforços de recuperação, utilizando como suporte as reclamações para desencadear as ações de melhorias, são monitorados por órgãos reguladores encarregados de fiscalizar e normalizar grande parte dos procedimentos da empresa. Desse modo, a empresa busca garantir que o serviço esteja sendo realizado conforme as normas e as resoluções estabelecidas, a fim de fornecer o atendimento adequado ao consumidor final.

\subsection{Análise geral}

$\mathrm{Na}$ empresa com alto grau de contato, as ações de recuperação desencadeadas são extremamente flexíveis e adaptáveis para cada situação em específico. Isso é devido ao fato de que a estrutura organizacional é reduzida e com forte estreitamento departamental, possibilitando receber as insatisfações diretamente pela diretoria ou colaboradores, tornando as ações de recuperação mais rápidas e dependentes da autonomia de cada colaborador da empresa. Com relação às melhorias dos processos, observou-se que: as principais ações são estabelecidas em reuniões gerais periódicas da empresa e a implementação e o controle são fortemente centrados no comprometimento dos colaboradores. Não foram observados controles formais e o uso de indicadores de desempenho. Por um lado, nota-se flexibilidade no processo de recuperação dos serviços e na implantação de

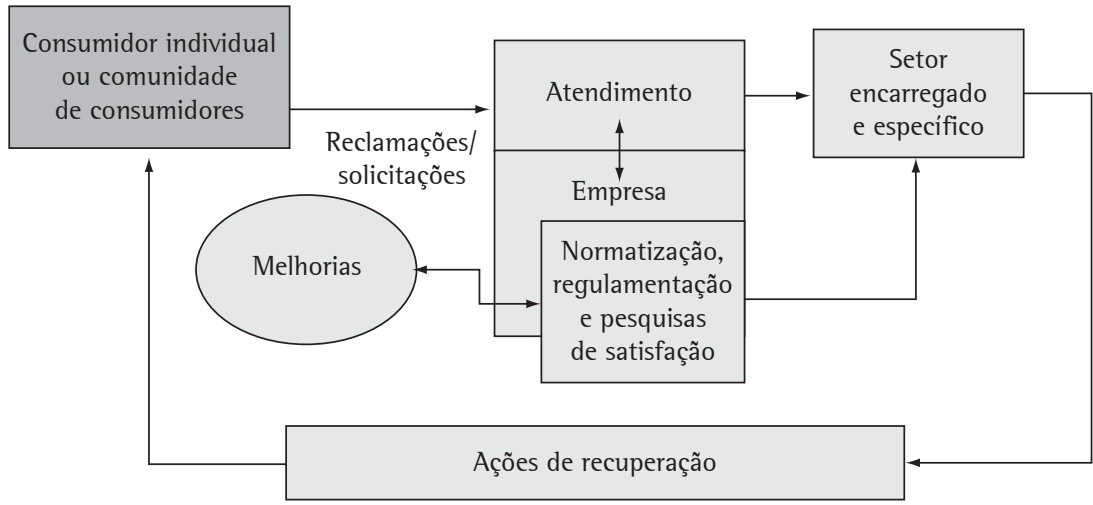

Figura 3. Recuperação e ações de melhorias através das reclamações. 
Quadro 7. Fatores que impactam a recuperação e as melhorias da empresa.

\begin{tabular}{|c|c|c|c|c|c|}
\hline \multicolumn{6}{|c|}{ Recuperação } \\
\hline Item & Atendimento & Relacionamento & Satisfação & Reclamações & Melhorias \\
\hline $\begin{array}{l}\text { Obtenção } \\
\text { de } \\
\text { informação }\end{array}$ & $\begin{array}{c}\text { Setor de } \\
\text { atendimento }\end{array}$ & $\begin{array}{l}\text { Por meio de } \\
\text { solicitações dos } \\
\text { clientes }\end{array}$ & $\begin{array}{l}\text { Pesquisas de } \\
\text { satisfação } \\
\text { externas }\end{array}$ & Tele-atendimento & $\begin{array}{l}\text { Reuniões do setor } \\
\text { de atendimento e } \\
\text { treinamentos dos } \\
\quad \text { funcionários }\end{array}$ \\
\hline $\begin{array}{l}\text { Contato } \\
\text { com } \\
\text { clientes }\end{array}$ & $\begin{array}{l}\text { Por telefone, site } \\
\text { da empresa ou } \\
\text { pessoalmente } \\
\text { pelo cliente }\end{array}$ & $\begin{array}{l}\text { Visitas a clientes } \\
\text { de grande porte } \\
\text { para firmar } \\
\text { relações }\end{array}$ & $\begin{array}{l}\text { Não adotam } \\
\text { pesquisas } \\
\text { internas } \\
\text { significativas }\end{array}$ & $\begin{array}{l}\text { Via tele- } \\
\text { atendimento, site } \\
\text { e pessoalmente } \\
\text { pelo cliente }\end{array}$ & $\begin{array}{c}\text { Uso das reclamações } \\
\text { para debate em } \\
\text { reuniões }\end{array}$ \\
\hline $\begin{array}{l}\text { Eficiência } \\
\quad \text { das } \\
\text { atividades }\end{array}$ & $\begin{array}{l}\text { Sob controle de } \\
\text { supervisores }\end{array}$ & $\begin{array}{c}\text { Não necessita } \\
\text { captar clientes. } \\
\text { Apenas em casos } \\
\text { de envolver } \\
\text { grandes empresas }\end{array}$ & $\begin{array}{l}\text { Órgãos } \\
\text { reguladores: } \\
\text { ANEEL e } \\
\text { AGERGS }\end{array}$ & $\begin{array}{l}\text { De acordo com o } \\
\text { setor responsável }\end{array}$ & $\begin{array}{c}\text { Baseadas nas pesquisas } \\
\text { de satisfação e } \\
\text { resoluções } \\
\text { pré-estabelecidas }\end{array}$ \\
\hline $\begin{array}{l}\text { Controle } \\
\text { dos } \\
\text { processos }\end{array}$ & $\begin{array}{l}\text { Normas de } \\
\text { atendimento: } \\
\text { resolução ANEEL }\end{array}$ & $\begin{array}{c}\text { Apenas por meio } \\
\text { de reuniões } \\
\text { realizadas }\end{array}$ & $\begin{array}{l}\text { Por meio de } \\
\text { indicadores } \\
\text { normalizados }\end{array}$ & $\begin{array}{l}\text { Sistema gerencial } \\
\text { corporativo }\end{array}$ & $\begin{array}{l}\text { Histórico das } \\
\text { reclamações, reuniões e } \\
\text { pesquisas de satisfação }\end{array}$ \\
\hline Empenho & $\begin{array}{c}\text { Para atendimento } \\
\text { das resoluções }\end{array}$ & $\begin{array}{l}\text { Foca-se em } \\
\text { atividades } \\
\text { emergenciais e } \\
\text { que necessitam } \\
\text { de reparos }\end{array}$ & $\begin{array}{l}\text { Base de dados } \\
\text { das pesquisas }\end{array}$ & $\begin{array}{l}\text { Central de } \\
\text { atendimento ao } \\
\text { consumidor }\end{array}$ & $\begin{array}{c}\text { Melhorias baseadas em } \\
\text { normas, resoluções e } \\
\text { procedimentos } \\
\text { pré-estabelecidos }\end{array}$ \\
\hline
\end{tabular}

melhorias nos processos. Por outro, nota-se como fragilidade a possível falta de registros formais acerca do desempenho da organização e dos níveis de satisfação dos clientes, como também acerca dos resultados das ações de recuperação, de modo que esses registros possam formar a memória da organização e auxiliar na tomada de decisões.

$\mathrm{Na}$ organização de médio grau de contato com o cliente final, as ações de recuperações dependem muito de programas de treinamento e devem obedecer aos procedimentos internos da empresa, necessitando do aval dos diretores. As reclamações são captadas através de pesquisas e contato telefônico direto, possibilitando a avaliação constante dos serviços prestados e a implementação das melhorias necessárias. Sistemas de informações gerenciais possibilitam acesso aos históricos de reclamações e das ações de recuperação estabelecidas. 0 desenvolvimento de ações de melhorias baseia-se também nas percepções do pessoal de linha de frente e nas reclamações dos clientes. Reuniões periódicas são efetuadas para acompanhamento da implementação das ações de melhorias e dos respectivos resultados.

Por fim, na organização de baixo contato, as ações de recuperação seguem o estabelecido em normas e procedimentos regulamentadores, que normatizam os processos internos da empresa. Destaca-se que a mesma deve obedecer a critérios legais dos órgãos reguladores. As informações e reclamações são obtidas por intermédio do call center ou de pesquisas externas realizadas por entidades responsáveis; as ações de melhorias são implementadas conforme necessidades e obedecem a critérios de processos gerenciais rígidos e pouco flexíveis, o que pode contribuir para a demora da recuperação de uma falha.

Pela própria limitação do método, um estudo de caso, destaca-se que não é possível generalizar os achados da pesquisa para todas as organizações com graus de contato e características similares às empresas estudadas. No entanto, com base em características gerenciais observadas na literatura e com base nas análises efetuadas sobre o processo de recuperação do serviço nas empresas estudadas, considerações mais genéricas são apresentadas. 0 Quadro 8 apresenta essas considerações.

Assim, as ações de melhorias são implementadas conforme o tipo de interação com o cliente, sendo que os procedimentos de recuperação de cada organização estudada estão diretamente ligados com os ciclos de melhorias. Cada empresa, devido ao seu grau de contato, deve observar como os 
Quadro 8. Características observadas nas empresas em estudo.

\begin{tabular}{|c|c|c|c|}
\hline $\begin{array}{l}\text { Grau de } \\
\text { contato }\end{array}$ & $\begin{array}{l}\text { Desafios gerenciais } \\
\text { (FITZSIMMONS J.; } \\
\text { FITZSIMMONS M., 2005) }\end{array}$ & $\begin{array}{l}\text { Características observadas nas } \\
\text { empresas em estudo, no que se } \\
\text { refere às ações de recuperação }\end{array}$ & Considerações gerais \\
\hline $\begin{array}{c}\text { Alto grau } \\
\text { de contato }\end{array}$ & $\begin{array}{c}\text { Cliente recebe atenção } \\
\text { individualizada de especialistas } \\
\text { altamente treinados. } \\
\text { Há dificuldade para desenvolver } \\
\text { métodos e controles. } \\
\text { O bem-estar do pessoal da } \\
\text { linha de frente influencia } \\
\text { diretamente a satisfação } \\
\text { dos clientes. } \\
\text { A gestão tende a ser } \\
\text { centralizada, dificultando o } \\
\text { crescimento da organização. } \\
\text { 0 conhecimento organizacional } \\
\text { está, muitas vezes, focado no } \\
\text { pessoal da linha de frente. } \\
\text { Gerenciar hierarquias } \\
\text { horizontais em que a relação } \\
\text { superior / subordinado é quase } \\
\text { inexistente. }\end{array}$ & $\begin{array}{l}\text { Cliente recebe atenção } \\
\text { individualizada. } \\
\text { Implementação e controle } \\
\text { das melhorias baseado no } \\
\text { comprometimento do pessoal. } \\
\text { Flexibilidade no processo de } \\
\text { recuperação, porém faltam } \\
\text { registros formais sobre } \\
\text { desempenho da organização e } \\
\text { satisfação dos clientes. }\end{array}$ & $\begin{array}{l}\text { O relacionamento com } \\
\text { cliente é fator decisivo para a } \\
\text { manutenção das decisões de } \\
\text { compra dos serviços. } \\
0 \text { comprometimento do } \\
\text { pessoal é fator alavancador da } \\
\text { satisfação dos clientes. } \\
\text { É necessário monitoramento do } \\
\text { desempenho da empresa. } \\
\text { É necessário conhecimento dos } \\
\text { níveis de satisfação dos clientes, } \\
\text { mesmo que obtido através das } \\
\text { percepções do pessoal da linha } \\
\text { de frente. }\end{array}$ \\
\hline $\begin{array}{l}\text { Médio grau de } \\
\text { contato }\end{array}$ & $\begin{array}{c}\text { Gerenciar a demanda para } \\
\text { evitar picos e para estimular a } \\
\text { demanda em períodos de baixa } \\
\text { pode ser fundamental, alinhado } \\
\text { a programação da prestação } \\
\text { dos serviços. } \\
\text { Processos mais operacionais, } \\
\text { onde ocorre a interação com } \\
\text { o cliente, requerem certa } \\
\text { padronização. É necessário } \\
\text { manter o controle da } \\
\text { intervenção dos clientes no } \\
\text { processo. } \\
\text { Obter a lealdade dos } \\
\text { funcionários. } \\
\text { Instalações físicas requerem } \\
\text { atenção especial, visto que } \\
\text { serão indicativos para o cliente } \\
\text { sobre o que esperar do serviço. } \\
\text { Manter os avanços } \\
\text { tecnológicos, lutando contra } \\
\text { aumento de custos. }\end{array}$ & $\begin{array}{l}\text { Procedimentos internos são } \\
\text { estabelecidos e há ênfase em } \\
\text { treinamento. } \\
\text { Pesquisas formais e contato } \\
\text { telefônico direto com o cliente } \\
\text { são efetuados periodicamente. } \\
\text { Existe um sistema de } \\
\text { informações gerenciais que } \\
\text { mantém o histórico das } \\
\text { reclamações dos clientes e das } \\
\text { ações estabelecidas. } \\
\text { Percepções do pessoal da linha } \\
\text { de frente são consideradas e } \\
\text { avaliadas. } \\
\text { Monitoramento e controle } \\
\text { periódicos. }\end{array}$ & $\begin{array}{l}\text { Estabelecer procedimentos } \\
\text { internos e capacitar } \\
\text { especialmente o pessoal } \\
\text { da linha de frente a lidar com } \\
\text { as mais diversas situações } \\
\text { possíveis decorrentes da } \\
\text { interação com o cliente. } \\
\text { Estabelecer claramente o nível } \\
\text { de autonomia do pessoal da } \\
\text { linha de frente para a tomada } \\
\text { de decisão, especialmente } \\
\text { quando o cliente aguarda uma } \\
\text { ação imediata. } \\
\text { Considerar a percepção do } \\
\text { pessoal da linha de frente no } \\
\text { que se refere ao atendimento e } \\
\text { ações de recuperação. } \\
\text { Ter e manter um sistema } \\
\text { de informações gerenciais } \\
\text { que permite monitorar } \\
\text { desempenho da empresa e } \\
\text { níveis de satisfação, ações } \\
\text { de recuperação, ações de } \\
\text { melhoria. }\end{array}$ \\
\hline $\begin{array}{l}\text { Baixo grau de } \\
\text { contato }\end{array}$ & $\begin{array}{c}\text { Administrar hierarquias } \\
\text { rígidas, com necessidade de } \\
\text { padronização de procedimentos } \\
\text { operacionais. } \\
\text { Desenvolver métodos } \\
\text { de controle. } \\
\text { Programação da força } \\
\text { de trabalho. } \\
\text { Tornar o serviço impessoal } \\
\text { em serviço "caloroso". } \\
\text { Gestão do crescimento. }\end{array}$ & $\begin{array}{c}\text { Normas e procedimentos } \\
\text { são rígidos, não havendo } \\
\text { autonomia do pessoal da linha } \\
\text { de frente. } \\
\text { 0 processo de recuperação de } \\
\text { uma falha pode ser demorado } \\
\text { pela rigidez dos processos. }\end{array}$ & $\begin{array}{l}\text { Ter objetivos claros quanto } \\
\text { aos prazos e ações de } \\
\text { recuperação dos serviços. } \\
\text { Ter normas e procedimentos } \\
\text { estabelecidos e disseminados. } \\
\text { Capacitar o pessoal da linha } \\
\text { de frente para tornar o serviço } \\
\text { mais "caloroso". }\end{array}$ \\
\hline
\end{tabular}


processos desencadeiam as ações para avanço das estratégias adotadas para realizar os procedimentos certos na prestação dos serviços. Devem-se priorizar detalhadamente os processos para que os mesmos sejam executados corretamente já na primeira vez, ou seja, para que os problemas nucleares dos serviços prestados não venham mais a ocorrer, causando a insatisfação dos consumidores. Gera-se, dessa maneira, o benefício de que as empresas podem desenvolver-se, adaptar-se e aprender através das experiências de recuperação e criar mecanismos adequados para atender as demandas e melhorar continuamente seus processos e procedimentos gerenciais.

\section{Considerações finais}

Este trabalho teve como objetivo geral analisar o processo de recuperação do serviço decorrente das reclamações dos clientes e analisar como as melhorias dos processos são gerenciadas nas empresas através da investigação em três estudos de casos.

A partir do estudo realizado nos três tipos de organizações, sejam estas de alto, médio ou baixo contato com o consumidor final, pode-se verificar que, dependendo da empresa ou do tipo de segmento em que atua, as ações de recuperação baseadas na obtenção das reclamações e das informações dos clientes obedecem à estrutura organizacional e dependem dos processos internos que cada empresa utiliza e executa.

Este estudo permitiu, portanto, uma melhor compreensão acerca da recuperação de serviços e do entendimento das ações desencadeadas, com base nas informações e reclamações dos consumidores. Verificou-se, também, como as reclamações podem gerar ações de melhorias nos processos das organizações.

Observa-se, com base na amostra estudada, que em empresa de alto e médio grau de contato, a satisfação do funcionário da linha de frente e seu comprometimento com a empresa são relevantes para que haja empenho nas ações de recuperação e para que as mesmas sejam eficazes. Quando há alto contato, a gestão pode ser menos centralizada e os níveis hierárquicos tendem a ser mais horizontais, o que pode facilitar a fluidez da comunicação interna e da comunicação com o cliente. Ademais, em se tratando de alto contato, o relacionamento interpessoal do pessoal da linha de frente com o cliente assume relevante importância para a manutenção do cliente. Nesse contexto, a recuperação do serviço é, via de regra, conduzida pela linha de frente que, por sua vez, tem certo grau de autonomia. Após análise do caso, sugere-se que seja dada atenção ao registro das ações e de seus resultados, pois a não padronização das ações e a autonomia dos funcionários podem levar à não existência de procedimentos básicos para o estabelecimento de ações de melhorias e ao não registro adequado de informações relevantes sobre as falhas, as reclamações e as respectivas recuperações.

Quando o nível de contato é médio, os processos tendem a ser mais padronizados. Os funcionários da linha de frente, embora tenham algum grau de autonomia, seguem claramente procedimentos definidos e inserem-se em uma hierarquia mais vertical. A gestão das informações sobre a satisfação dos clientes e sobre as ações de recuperação assume maior importância. As instalações físicas podem ser relevantes e dar pistas aos clientes sobre o que esperar do serviço. Assim, a atenção do gestor é elemento essencial, visto que as interações são constantes no varejo e a variedade de público costuma ser significativa.

Já no caso de serviços com baixo contato, observa-se elevada padronização. A ênfase da organização pode estar focada em maximizar o uso da estrutura. Não há serviços customizados e as relações diretas com os clientes são mínimas, muitas vezes centradas principalmente na solução de problemas. Sugere-se um permanente questionamento dos processos, a fim de evitar rigidez e lentidão na tomada de decisão.

Entende-se que o tema recuperação de falhas em serviços apresenta oportunidades de estudos. Como continuidade dos trabalhos, sugere-se avaliar o nível efetivo de satisfação dos clientes com as ações de recuperação para serviços, independentemente se estes são de alto, médio ou baixo contato. Da mesma forma, identificar o tipo de ação com maior impacto na percepção dos clientes poderá contribuir para um melhor desempenho das organizações.

\section{Referências}

ANDREASSEN, T. Antecedents to satisfaction with service recovery. European Journal of Marketing, v. 34, n. 12 , p. 156-175, 2000.

BATESON, J.; HOFFMAN, K. Marketing de serviços. Porto Alegre: Bookman, 2001.

BEHARA, R.; GUNDERSEN, D. Analysis of quality management practices in services. International Journal of Quality \& Reliability Management, v. 18, n. 6, p. 584-603, 2001.

BERRY, L. Descobrindo a essência do serviço. Rio de Janeiro: Qualitymark, 2001.

BOSCH, V.; ENRÍQUEZ, F. TQM and QFD: exploit a customer complaint management system. International Journal of Quality \& Reliability Management, v. 22, n. 1, p. 30-37, 2006. 
COYE, R. Managing customer expectations in the service encounter. International Journal of Service Industry Management, v. 15, n. 1, p. 54-71, 2004.

FITZSIMMONS, J.; FITZSIMMONS, M. Administração de serviços: operações, estratégia e tecnologia de Informação. Porto Alegre: Bookman, 2005.

GLYNN, W. et al. Listening practices and performance in service organisations. International Journal of Service Industry Management, v. 14, n. 3, p. 310-330, 2003.

HOCUTT, M.; BOWERS, M.; DONAVAN, D. The art of service recovery: fact or fiction? Journal of Services Marketing, v. 20 , n. 3, p. 199-207, 2006.

HUANG, W. The impact of other-customer failure on service satisfaction. International Journal of Service Industry Management, v. 19, n. 4, p. 521-536, 2008.

HUQ, Z. Managing change: a barrier to TQM implementation in service industries. Managing Service Quality, v. 15, n. 5, p. 452-469, 2005.

JOHNSTON, R. Linking complaint management to profit. International Journal of Service Industry Management, v. 12, n. 1, p. 60-69, 2001.

JOHNSTON, R. Service operations management: return to roots. International Journals of Operations \& Production Management, v. 25, n. 2, p. 1278-1297, 2005.

JOHNSTON, R.; MICHEL, S. Three outcomes of service recovery: customer recovery, process recovery and employee recovery. International Journal of Operations \& Production Management, v. 28, n. 1, p. 79-99, 2008.

$\mathrm{KAU}, \mathrm{A}$; $\mathrm{LOH}$, E. The effects of service recovery on consumer satisfaction: a comparison between complaints and non-complaints. Journal of Services Marketing, v. 20, n. 2, p. 101-111, 2006.

LAGROSEN, S.; LAGROSEN, Y. Management of service quality - differences in values, practices and outcomes. Managing Service Quality, v. 13, n. 5, p. 370-381, 2003.

LIDÉN, S.; SKALÉN, P. The effect of service guarantees on service recovery. International Journal of Service Industry Management, v. 14, n. 1, p. 36-58, 2003.
LOVELOCK, C.; WRIGHT, L. Serviços: marketing e gestão. São Paulo: Saraiva, 2004.

MATTILA, A. The effectiveness of service recovery in a multi-industry setting. Journal of Services Marketing, v. 15, n. 7, p. 583-596, 2001.

MATTILA, A.; CRANAGE, D. The impact of choice on fairness in the context of service recovery. Journal of Services Marketing, v. 19, n. 5, p. 271-279, 2005.

MICHEL, S. Analyzing service failures and recoveries: a process approach. International Journal of Service Industry Management, v. 12, n. 1, p. 20-33, 2001.

MICHEL, S.; MEUTER, M. The service recovery paradox: true but overrated? International Journal of Service Industry Management, v. 19, n. 4, p. 441-457, 2008.

PRAJOGO, D. The comparative analysis of TQM practices and quality performance between manufacturing and service firms. International Journal of Service Industry Management, v. 16, n. 3, p. 217-228, 2005.

SIMONS Jr., J. Reliability-based analysis of service recovery. International Journal of Quality and Reliability Management, v. 21, n. 1, 2004.

STAUSS, B. The dimensions of complaint satisfaction: process and outcome complaint satisfaction versus cold fact and warm act complaint satisfaction. Managing Service Quality, v. 12, n. 3, p. 173-183, 2002.

SURESCHCHANDAR, G.; RAJENDRAN, C.; ANANTHARAMAN, R. A holistic model for total quality service. International Journal of Service Industry Management, v. 12, n. 4, p. 378-412, 2001.

VOSS, C.; TSIKRIKTSIS, N.; FROHLICH, M. Case research in operations management. International Journal of Operations \& Production Management, v. 22, n. 2, p. 195-219, 2002.

YIN, R. Estudo de caso: planejamento e método. Porto Alegre: Bookman, 2001.

ZEITHAML, V.; BITNER, M. Marketing de serviços: a empresa com foco no cliente. Porto Alegre: Bookman, 2003.

\title{
Analysis of the process of service recovery from customer complaints: case study in three organizations
}

\begin{abstract}
This paper presents an analysis of the process of service recovery based on customer complaints and also how improvement processes are handled within the companies. The paper presents concepts related to expectations and perceptions, flaws and complaints, service recovery and improvement in the quality of services. The method used in the research was the case study. The case studies were taken from three companies: a company with a high degree of contact with customers and customized service, a company operating within retail with a medium degree of contact, and a mass service company with very limited customer contact. At the end of the research, results are discussed and areas for continued research continuity are defined. The findings of this research suggest the need for a service recovery strategy linked to an improvement in processes in order to provide the correct initial service.
\end{abstract}

Keywords

Service recovery. Customer complaint. Service process improvement. 